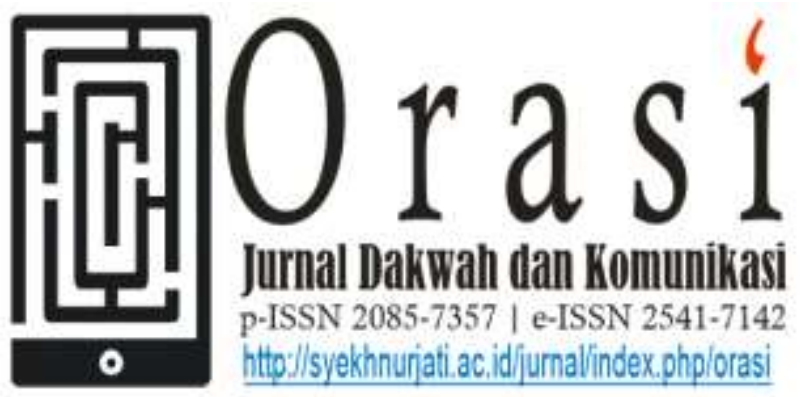

Volume 12 No. 1 Juli 2021

\title{
MAKNA HIJRAH PADA ANGGOTA GERAKAN \#INDONESIATANPAPACARAN
}

\section{HIJRAH'S MEANING AMONG THE FOLLOWERS OF \#INDONESIATANPAPACARAN MOVEMENT}

\author{
Muhammad Zaki \\ Prodi Komunikasi dan Penyiaran Islam, Pascasarjana UIN Sunan Ampel Surabaya \\ e-mail :muhzaki149@gmail.com
}

\begin{abstract}
ABSTRAK
Tren hijrah yang ada saat ini diikuti dengan menguatnya wacana konservatisme. Salah satu gerakan yang ikut dalam menyebarkan nilai konservatif tersebut adalah \#IndonesiaTanpaPacaran. Gerakan ini menggunakan framing ajakan berhijrah untuk mendapatkan dukungan dalam rangka mencapai tujuannya menegakkan syariat Islam di masyarakat. Mereka diindikasikan berusaha merubah ideologi para anggota yang direkrut dengan mempropagandakan pemaknaan hijrah versi mereka. Hal ini dapat berbahaya mengingat gerakan ini memiliki kedekatan dengan Hizbut Tahrir Indonesia, organisasi yang telah dibubarkan oleh Pemerintah Indonesia. Oleh karena itu penelitian ini bertujuan mendalami bagaimana pengalaman dan pemaknaan hijrah yang dilakukan oleh para anggota gerakan \#IndonesiaTanpaPacaran untuk mengetahui apakah propaganda hijrah yang dilakukan gerakan ini telah berhasil merubah ideologi anggotanya. Fenomenologi Husserl dan Alfred Schutz digunakan untuk menggali pengalaman dan makna hijrah dari sudur pandang para anggota gerakan \#IndonesiaTanpaPacaran secara natural sehingga dapat ditemukan bahwa para anggota gerakan \#IndonesiaTanpaPacaran memiliki pengalaman hijrah yang tidak banyak dipengaruhi oleh gerakan \#IndonesiaTanpaPacaran dan mereka memaknai hijrah sebagai perubahan perilaku dari buruk menjadi baik sesuai dengan ajaran Islam. Kebanyakan dari mereka tidak memiliki keinginan yang sama dengan gerakan \#IndonesiaTanpaPacaran untuk menegakkan syariat Islam di masyarakat dan memiliki paham Islam yang cenderung berbeda dengan gerakan tersebut.
\end{abstract}

Kata Kunci: Indonesia Tanpa Pacaran, Konservatif, Makna Hijrah 


\begin{abstract}
The trend of hijrah nowadays is followed by the strengthening of the conservatism discourse. One of the movements involved in spreading these conservative values is \#IndonesiaTanpaPacaran. This movement uses the "call for hijrah" framing to gain support in order to achieve its goal of enforcing Islamic law in society. The followers of this movement are indicated to try to change the ideology of the new recruited followers by propagating their version of the meaning of hijrah. This can be dangerous given that the movement has close ties to Hizb ut-Tahrir Indonesia, an organization that has been dissolved by the Indonesian government. Therefore, this study aimed to explore how the experience and meaning of hijrah carried out by the followers of the \#IndonesiaTanpaPacaran movement were to find out whether the hijrah propaganda had succeeded in changing the ideology of the followers. The phenomenology of Husserl and Alfred Schutz was used to explore the experience and meaning of hijrah from the point of view of the \#IndonesiaTanpaPacaran movement's followers naturally. The results show that the followers of the \#IndonesiaTanpaPacaran movement had experiences of hijrah which were not much influenced by the \#IndonesiaTanpaPacaran movement and they interpreted hijrah as a change in behavior from bad to good according to Islamic teachings. Most of them did not have the same desire as the \#IndonesiaTanpaPacaran movement, to enforce Islamic law in society, and had an Islamic understanding that tended to be different from the movement.
\end{abstract}

Keywords: Indonesia Tanpa Pacaran, Conservative, Hijrah's Meaning

\section{Pendahuluan}

Tren hijrah yang terjadi pada pemuda muslim di Indonesia saat ini seringkali dikaitkan dengan menguatnya wacana konservatisme, salah satunya karena kebanyakan pihak yang mempopulerkannya adalah figur-figur yang mendukung konsep negara Islam yang diusung oleh Hizbut Tahrir (Nuriz 2019). Istilah "konservatif" sendiri mengacu pada berbagai arus yang mengharuskan untuk patuh terhadap doktrin dan tatanan sosial yang telah mapan dalam ajaran Islam dan mengharuskan penggunaan pendekatan yang lebih literal dan kaku dalam memahami teks-teks ajaran Islam (Bruinessen 2013). Kaum konservatif cenderung memiliki cita-cita untuk menegakkan syariat Islam yang sumbernya dari penafsiran teks ajaran Islam yang literal dan kaku, seperti pemberlakuan sanksi potong tangan bagi pencuri, cambuk atau rajam bagi pezina, dan sebagainya; serta menentang sekaligus ingin mengganti semua sistem lain yang tidak sesuai dengan sistem Islam.

Salah satu gerakan hijrah yang membawa paham konservatif dan banyak mendapatkan sorotan dalam beberapa tahun belakangan ini adalah gerakan \#IndonesiaTanpaPacaran (ITP). Gerakan ini diindikasikan kuat memiliki afiliasi dengan organisasi Hizbut Tahrir Indonesia (HTI). Pendiri ITP, La Ode Munafar, dulunya merupakan kader HTI yang cukup idealis dan dekat dengan beberapa pimpinan pusat HTI. Beberapa posisi penting di ITP pun juga diberikan oleh La Ode kepada temantemannya di HTI (Sari 2019). 
Secara pemikiran La Ode juga memiliki kesamaan dengan HTI. ITP yang sebenarnya memiliki visi untuk "menjadi barisan terdepan berjuang menghapus pacaran dari Indonesia", namun dalam kenyataannya memiliki agenda lebih besar untuk menegakkan syariat Islam. Menurut La Ode (2018) solusi untuk menghilangkan budaya pacaran adalah dengan merubah sistem negara dari yang sekuler menjadi berlandaskan Islam. Ia mencontohkan salah satu penerapan sistem Islam tersebut adalah dengan memberi hukuman cambuk pada pezina, yang menunjukkan bahwa pemahamannya terhadap syariat Islam bersumber dari penafsiran yang cenderung literal dan kaku. Pemikiran La Ode ini identik dengan pemikiran HTI yang memandang bahwa setiap persoalan sosial, apapun bentuknya, solusinya selalu dengan penegakkan syariat Islam (Ahnaf 2018).

ITP berusaha mendapatkan dukungan melalui beberapa cara untuk mencapai tujuannya menegakkan syariat Islam, salah satunya adalah dengan mempropagandakan framing "panggilan untuk hijrah". Melalui framing ini ITP mempropagandakan pemaknaan hijrah yang tidak hanya mencakup perubahan secara penampilan namun juga secara ideologi (Sari 2019). Panggilan hijrah ini dijadikan ITP sebagai alat untuk merekrut anggota yang kemudian -dengan pemaknaan hijrah versi mereka- juga digunakan sebagai upaya mengajak para anggota yang terekrut untuk bersama-sama memperjuangkan ideologi mereka (Sari 2019).

Kata "hijrah" sendiri secara etimologis berasal dari bahasa Arab yang pada dasarnya tersusun dari huruf-huruf ha, jim dan $r a$ (hajara) dengan dua pokok kandungan makna. Pertama, hijrah berarti putus pada satu sisi dan persambungan pada sisi lain. Misalnya: sekelompok orang meninggalkan sebuah perkampungan menuju perkampungan lainnya. Kedua, hijrah dapat berarti telaga yang luas, dikatakan demikian karena telaga itu merupakan sesuatu yang menghentikan air (Aswadi 2011). Ibnu Qayim Al-Jauziyah (2002) berpendapat bahwa hijrah dapat dibagi menjadi dua, pertama adalah hijrah fisik yang artinya berpindah dari sebuah negeri menuju negeri yang lain; kedua hijrah hati kepada Allah dan Rosul-Nya yang menurutnya merupakan hijrah yang hakiki dan hijrah yang inti, dimana hijrah fisik merupakan cabang dari hijrah ini. Al-Jauziyah menambahkan bahwa hijrah memiliki kandungan pengertian dari (sesuatu) kepada (sesuatu), yang artinya hijrah mempunyai titik tolak dan tujuan yang hendak dicapai. Oleh karena itu hijrah harusnya selalu bertitik tolak dari yang awalnya berorientasi pada sesuatu yang selain Allah untuk kemudian berubah menjadi berorientasi pada Allah. Inilah yang disebut oleh Al-Jauziyah sebagai alfirar ilallah atau berlari menuju Allah, seperti dalam firman Allah surat Adz-Dzariyat ayat 50:

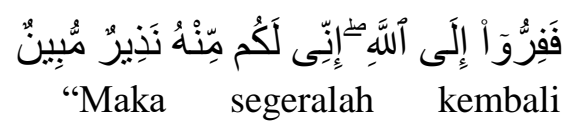
kepada (menaati) Allah. Sesungguhnya aku seorang pemberi peringatan yang nyata dari Allah untukmu."

Nuriz (2019) berpendapat bahwa istilah "hijrah" yang populer saat ini pada generasi muda cenderung merujuk pada 
pengertian hijrah sebagai suatu upaya perubahan perilaku dari buruk menjadi baik, atau dapat juga disebut sebagai perubahan perilaku dari awalnya kurang taat terhadap aturan Islam menjadi lebih taat menjalankan aturan atau syariat Islam. "Taat menjalankan syariat Islam" dapat dimaknai melalui berbagai pendekatan yang kemudian dapat melahirkan pelaksanaan yang berbeda-beda. Pendekatan yang cenderung literal dan kaku terhadap sumber-sumber ajaran Islam dalam memaknai hijrah dan syariat Islam dapat melahirkan berbagai pemikiran yang konservatif bahkan radikal terhadap ajaran Islam, yang kemudian akan mempengaruhi bagaimana seseorang mengaplikasikan hijrahnya dalam perilaku sehari-hari.

Dalam fenomenologi manusia dianggap akan melakukan proses pemaknaan terhadap pengalaman mereka secara aktif, sehingga mereka dapat memahami lingkungannya melalui pengalaman personal dan langsung dengan lingkungan (Morissan 2015). Anggota yang direkrut ITP akan secara aktif memaknai pengalaman hijrahnya. Apabila pengalaman tersebut banyak dipengaruhi oleh ITP maka mereka akan berpotensi memiliki paham hijrah yang sama dengan ITP dan akan menerapkannya dalam kehidupan sosial mereka. Situasi berpotensi menimbulkan masalah karena konsep hijrah yang dibawa oleh ITP dapat menanamkan paham konservatif yang membuat anggotanya memiliki cita-cita untuk menegakkan syariat Islam yang bersumber dari penafsiran teks ajaran Islam yang literal dan kaku. Paham ini dapat melunturkan rasa nasionalisme seseorang karena memandang bahwa negara Indonesia beserta konstitusi dan sistem pemerintahannya adalah kufur karena tidak menerapkan "syariat Islam".

Permasalahan yang dijelaskan sebelumnya tersebut hanya akan muncul apabila pengalaman hijrah para anggota ITP banyak dipengaruhi oleh ITP dan mereka memaknai hijrah sesuai konsep hijrah yang dibawakan oleh ITP. Maka dari itu penelitian ini dilakukan untuk mendalami bagaimana pengalaman dan pemaknaan hijrah yang dilakukan oleh anggota ITP, sebagai salah satu upaya untuk mengetahui apakah propaganda hijrah ITP telah mengakibatkan anggotanya memiliki paham konservatif layaknya mereka.

\section{Metodologi Penelitian}

Penelitian ini adalah penelitian kualitatif mengingat yang hendak dikaji adalah makna terhadap suatu hal atau pengalaman. Seperti yang diungkapkan oleh Steven J. Taylor, dkk (2016) bahwa peneliti kualitatif akan berfokus pada pemaknaan dari seseorang terhadap sesuatu dalam hidupnya. Sedangkan pendekatan dari penelitian ini adalah fenomenologi karena berusaha untuk mendeskripsikan pengalaman dan pemaknaan umum dari sejumlah anggota ITP tentang hijrah. Ini sesuai dengan apa yang disebutkan oleh Creswell (2015) bahwa peneliti fenomenologi berkonsentrasi untuk mendeskripsikan apa yang sama/umum dari semua partisipan ketika mereka mengalami fenomena.

Upaya pengumpulan data dalam penelitian ini dilakukan dengan wawancara 
mendalam, observasi berperan serta, dan dokumentasi. Wawancara mendalam dilakukan terhadap 14 orang anggota ITP yang telah memiliki pengalaman hijrah dan telah bergabung dengan ITP setidaknya selama 6 bulan, sebagai acuan bahwa mereka telah cukup lama berinteraksi di dalam lingkungan ITP. 14 responden tersebut terdiri dari 7 responden berjenis kelamin laki-laki dan 7 responden berjenis kelamin perempuan. Sedangkan observasi berperan serta dilakukan penulis dengan ikut serta menjadi anggota ITP, untuk bisa memiliki pengalaman yang sama sebagai sesama anggota. Dokumentasi dilakukan dengan mengumpulkan segala tulisan di buku maupun laman resmi ITP dan unggahan atau percakapan di akun media sosial anggota dan akun resmi milik ITP. Datadata berupa penjelasan akan pengalaman tersebut kemudian dianalisis makna dan kedalamannya menggunakan fenomenologi transendental dari Husserl yang dikombinasikan dengan fenomenologi Schutz.

Fenomenologi Husserl diarahkan untuk mendeskripsikan cara kenyataan dalam menyingkapkan dirinya pada kesadaran, tanpa kontaminasi berbagai konstruksi teoritis, entah berasal dari filsafat ataupun ilmu pengetahuan. Tujuannya adalah untuk menyibak sudut pandang secara natural. Hal ini menuntut pengarahan kesadaran secara langsung kepada objeknya, tanpa dimediasi oleh apapun dan harus bebas dari segala macam prasangka. Artinya, diperlukan langkah-langkah metodis tersendiri untuk membiarkan realitas berbicara atas namanya sendiri. Metode ini kemudian dikenal dengan epoche (Ardian 2016).
Metode Epoche dilakukan dengan mengeliminasi secara cermat dan sistematis terhadap setiap faktor subjektif yang masuk ke dalam pengalaman murni seseorang dengan suatu peristiwa/benda. Dalam pereduksian ini, orang akan menyingkirkan faktor-faktor subjektif untuk menghilangkan unsur-unsur yang mengakibatkan terjadinya penyimpangan serta memusatkan perhatian pada objek yang ingin diteliti. Kesadaran murni seseorang mengenai suatu objek akan mengungkapkan esensi yang sebenarnya dari suatu fenomena (Syam 2015).

Hijrah yang dilakukan oleh para anggota ITP merupakan pengalaman mereka dalam menjalani suatu peristiwa, dalam hal ini perubahan perilaku dari buruk menjadi baik. Dengan ecpoche maka peneliti harus fokus terhadap bagaimana hijrah muncul dalam kesadaran subjek anggota ITP tanpa kontaminasi konstruksi teoritis apapun sehingga dapat mengungkap sudut pandang anggota ITP terhadap hijrah secara natural.

Hijrah sebagai sebuah upaya transformasi diri, output-nya adalah untuk dapat memiliki perilaku yang dianggap baik atau sesuai dengan ajaran Islam. Konsep perilaku yang baik, norma, dan sebagainya tersebut diistilahkan oleh Schutz sebagai stok pengetahuan (stock of knowledge), yang merupakan suatu kerangka referensi bagi seseorang dalam menginterpretasi segala sesuatu yang terjadi di sekitarnya sebelum melakukan tindakan (Haryanto 2012).

Stok pengetahuan seseorang dibentuk melalui pengalaman, baik pengalamannya sendiri maupun pengalaman orang lain yang 
dibagikan (Zahavi 2019). Seseorang yang berhijrah kemungkinan besar telah mengalami perubahan dalam stok pengetahuannya, karena apa yang menurut mereka baik bisa jadi tidaklah sama antara sebelum dan sesudah berhijrah. Contohnya, mereka yang dulu mungkin masih membenarkan perilaku pacaran setelah hijrah akan mengharamkannya karena dianggap dilarang dalam Islam. Disinilah kemudian fenomenologi Schutz akan digunakan sebagai alat dalam menganalisa data-data mengenai pengalaman hijrah ataupun makna hijrah para anggota ITP.

\section{Hasil dan Pembahasan}

\subsection{Gerakan \#IndonesiaTanpaPacaran}

Gerakan ITP didirikan pada tanggal 7

September 2015 oleh La Ode Munafar karena ia menganggap bahwa pacaran dan pergaulan bebas merusak dan merugikan generasi muda dipandang dari sisi manapun (IDN Times 2018). ITP memiliki visi untuk "menjadi barisan terdepan berjuang menghapus pacaran dari Indonesia". Untuk mencapai visi tersebut mereka memiliki tiga misi: pertama, memahamkan generasi dari bahaya pacaran; kedua, merangkul generasi yang sedang dan/atau sudah terjebak dalam pacaran; dan ketiga, memberikan solusi pada pemuda cara ekspresi cinta tanpa pacaran (Indonesiatanpapacaran 2017).

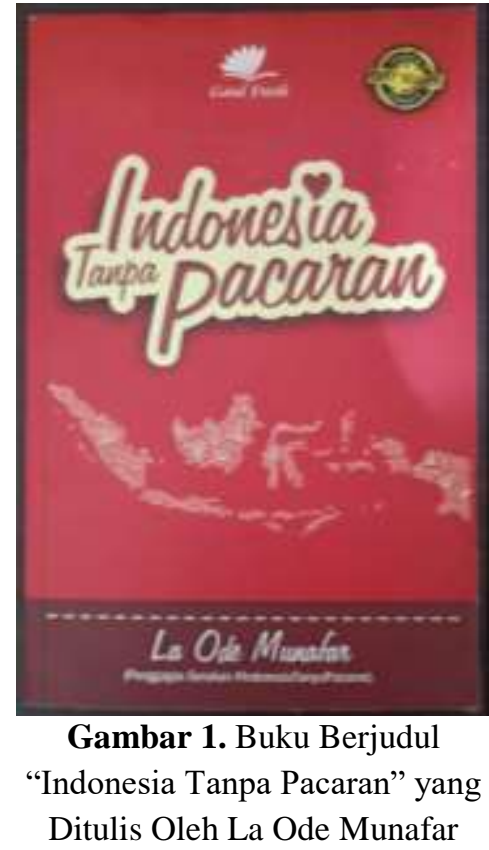

Visi ITP untuk menghapus pacaran dari Indonesia dapat dikatakan sebagai efek dari agenda besar mereka yang sesungguhnya. Ini karena keinginan mereka sebenarnya adalah untuk merubah sistem negara dari sekuler menjadi berlandaskan Islam. Dalam buku berjudul "Indonesia Tanpa Pacaran" yang ditulis La Ode Munafar (2018) -buku yang berisi semacam konsep mengenai arah gerakan ITP- menyebutkan bahwa segala kerusakan yang ada di masyarakat, termasuk pacaran, pangkal penyebabnya adalah pelanggaran dan penyimpangan manusia terhadap ketentuan syariat Islam.

Ia juga menyampaikan bahwa tidak ada satu masyarakatpun di dunia ini yang sesuai dengan Islam, termasuk di Indonesia. La Ode bahkan berani secara tegas menyatakan bahwa Indonesia saat ini menganut paham sekulerisme. Alasannya diantaranya adalah karena di Indonesia wanita 
bebas tidak menutup aurat saat keluar rumah; laki-laki dan perempuan dipisah hanya ketika di masjid, tidak berlaku di kehidupan masyarakat sehari-hari lainnya; dan pengaturan negara yang dilakukan tanpa embel-embel agama. Oleh karena itu menurutnya masyarakat Indonesia saat ini bukan merupakan masyarakat Islam. Sekuler sendiri didefinisikan oleh La Ode sebagai "paham yang memisahkan agama dari kehidupan. Agama tidak boleh mengatur urusan pergaulan, budaya, pendidikan, bermasyarakat, berbangsa dan bernegara. Agama cukup di masjid aja."

Pemahaman bahwa sekulerisme merupakan sumber dari semua persoalan membawa La Ode pada kesimpulan bahwa solusi dari masalah pacaran, beserta semua masalah sosial lainnya, adalah dengan menerapkan syariat Islam dalam kehidupan masyarakat. Solusi ini dijadikan sebagai salah satu poin dalam deklarasi yang pernah diucapkan bersama-sama oleh para peserta temu nasional ITP di tahun 2018, yang berbunyi: "Kami siap memperjuangkan kembalinya syariah Islam, dalam kehidupan sehari-hari demi terwujudnya Indonesia tanpa pacaran."1

Pemikiran La Ode di atas nampaknya didapatkan dari HTI, yang diakuinya diikutinya sejak tahun 2008, atau sejak ia duduk di bangku SMA. ITP sendiri memang diindikasikan secara kuat memiliki afiliasi

\footnotetext{
${ }^{1}$ Teks deklarasi ini adalah tulisan yang tertera pada gambar yang diunggah oleh La Ode Munafar di akun Instagram pribadinya pada tanggal 16 April 2018. Link dari unggahan tersebut dapat dilihat di: https://www.instagram.com/p/BhnbdrMlj-b/
}

dengan HTI, organisasi yang telah dibubarkan oleh Pemerintah Indonesia pada tahun 2017 karena dianggap bertentangan dengan Pancasila dan UUD 1945 (Kompas.com 2017). Adanya indikasi ITP berafiliasi dengan HTI ini selain karena La Ode yang merupakan mantan kader HTI, juga karena beberapa pengurus ITP pusat yang diisi oleh teman-teman La Ode di HTI.

Secara pemikiran ITP pun memiliki kemiripan dengan HTI, terutama dalam mengambil pendekatan untuk menyelesaikan setiap permasalahan sosial. Mereka sama-sama menganggap bahwa akar dari semua masalah masyarakat adalah karena tidak diterapkannya syariat Islam sehingga untuk menyelesaikannya harus secara fundamental dari akarnya dengan merubah sistem agar berlandaskan Islam. Yang membedakan hanya tidak digunakannya tambahan istilah "khilafah Islamiyah" sebagai model kepemimpinan yang menjalankan sistem Islami tersebut. Ini nampaknya disengaja untuk menghindari delik dan pertentangan di masyarakat karena istilah "khilafah" cukup melekat dengan HTI yang telah dibubarkan oleh pemerintah dan karena istilah tersebut juga digunakan oleh beberapa kelompok Islam radikal semacam ISIS sebagai basis ideologinya.

ITP bisa dikatakan sebagai gerakan yang cukup banyak mendapatkan perhatian dari masyarakat, utamanya di media sosial. Ini karena mereka memang cukup populer di beberapa kanal media sosial. Di Instagram, ITP memiliki 1 juta pengikut. Sedangkan di Facebook, fanpage mereka disukai oleh 485 ribu akun dan grup resmi pendukung mereka 
memiliki sekitar 876,776 anggota. $^{2}$ ITP juga beberapa kali memicu kontroversi di masyarakat dikarenakan beberapa pemberitaan dan kampanye yang mereka lakukan di media sosial. Misalnya saja ketika ada pemberitaan mengenai komersialisasi agama oleh ITP lewat bisnis yang mereka jalankan (CNN Indonesia 2019; Tirto.id 2018; Geotimes 2018); kampanye nikah muda dan pembolehan mereka kepada anak di bawah usia 19 tahun untuk menikah meskipun dilarang oleh Undang-undang, ${ }^{3}$ dan sebagainya.

Popularitas ITP di media sosial nampaknya tidak sejalan dengan besarnya pengaruh pemikiran mereka di masyarakat. Berdasarkan temuan penulis, dari 14 orang anggota ITP yang menjadi informan dalam penelitian ini, hanya satu yang membaca buku "Indonesia Tanpa Pacaran". Padahal buku tersebut berisi pemikiran yang melandasi gerakan ITP sekaligus menjelaskan arah gerakan mereka. Video-video ceramah yang diunggah oleh ITP di Youtube dalam 3 bulan terakhir juga rata-rata dilihat kurang dari 500 kali saja. Hanya ada satu video yang penontonnya berjumlah lebih dari 1000 . Beberapa video live mereka di Youtube pun hanya dilihat oleh sekitar $10-20$ orang saja. Padahal konten-konten tersebutlah yang sebenarnya lebih menunjukkan identitas pemikiran mereka. Berbeda dengan unggahanunggahan di Instagram atau Facebook, yang isi

\footnotetext{
${ }^{2}$ Data ini berdasarkan pengamatan penulis pada akun-akun tersebut tanggal 20 September 2020.

${ }^{3}$ Ini berdasarkan video liputan BBC terhadap ITP yang diunggah oleh akun @ restyworo pada tanggal 29 April 2020 di tautan berikut: https://twitter.com/i/status/1255380923153080322.
}

pesannya cenderung umum dan hanya terdiri dari kalimat-kalimat pendek saja.

$$
\text { Sebagai suatu gerakan yang }
$$
terorganisir, ITP memiliki kepengurusan yang dibagi dua yakni pengurus ITP pusat, yang mengordinir ITP secara makro, dan pengurus ITP daerah atau "ITP regional", yang merupakan kepengurusan ITP di daerahdaerah, setingkat kabupaten/kota atau setingkat provinsi, yang telah diakui secara resmi oleh ITP pusat. Mereka memiliki sekitar 68 akun ITP regional, yang mengindikasikan jumlah kepengurusan regional yang dinaungi. Meski demikian, dari 68 akun tersebut, 30 diantaranya nampak sudah tidak aktif. Mereka terakhir mengunggah suatu konten pada tahun 2019 atau 2018, bahkan ada yang melakukan unggahan terakhirnya di tahun 2017. Sedangkan 38 akun lainnya yang ditemukan penulis nampak masih ada unggahan di tahun 2020 namun tidak semuanya cukup aktif atau intens dalam mengunggah konten.

\subsection{Cara Rekrutmen Anggota yang Dilakukan oleh Gerakan \#IndonesiaTanpaPacaran}

ITP memiliki program member dan membaginya menjadi dua, yakni member eksekutif dan member regional. Berdasarkan observasi penulis adanya penggolongan member di ITP dimulai sejak tahun 2018, dimana pada saat itu ITP telah memberlakukan pendaftaran berbayar melalui daring. Di awal berdirinya tahun 2015 anggota ITP tidak dibeda-bedakan karena sebenarnya ITP pada waktu itu adalah wadah untuk orang-orang yang menyukai buku "Indonesia Tanpa Pacaran”. Tahun 2016 sampai 2017, setiap 
mereka yang membeli buku tersebut kemudian juga dijadikan sebagai anggota ITP, dengan diberikan ID card dan dimasukkan dalam grup-grup ITP di berbagai media sosial.

Penggolongan anggota di ITP terjadi sejak tahun 2018 dikarenakan mereka mulai memberlakukan pendaftaran anggota melalui daring secara berbayar. Mereka yang mendaftar melalui proses ini kemudian dikategorikan sebagai "anggota eksekutif". Pada tahun 2019 dan 2020 biaya pendaftaran yang dibebankan adalah 198 ribu rupiah dan sebagai gantinya mendapatkan ID card, stiker, pin, dan sebuah buku. Pada tahun 2019 buku yang diberikan berjudul "Hati-hati Muslihat Lelaki" sedangkan pada tahun 2020 anggota eksekutif mendapatkan buku berjudul "\#IndonesiaTanpaPacaran", yang keduanya ditulis oleh La Ode Munafar.

Anggota eksekutif ITP akan tergabung dalam grup Whatsapp serta dapat masuk dalam grup Facebook khusus. Di tiap grup akan diunggah materi kajian secara rutin, biasanya seminggu sekali, dalam bentuk video atau berupa tulisan yang berformat PDF. Pada tahun 2020 kajian-kajian dalam bentuk video diunggah pula di akun Youtube resmi milik ITP, sehingga tanpa mendaftar menjadi anggota eksekutif pun sebenarnya tiap orang bisa mengakses video kajian tersebut. Anggota ITP eksekutif disebutkan dapat juga tergabung dalam keanggotaan daerah bila memang di tempatya tinggal terdapat ITP regional.

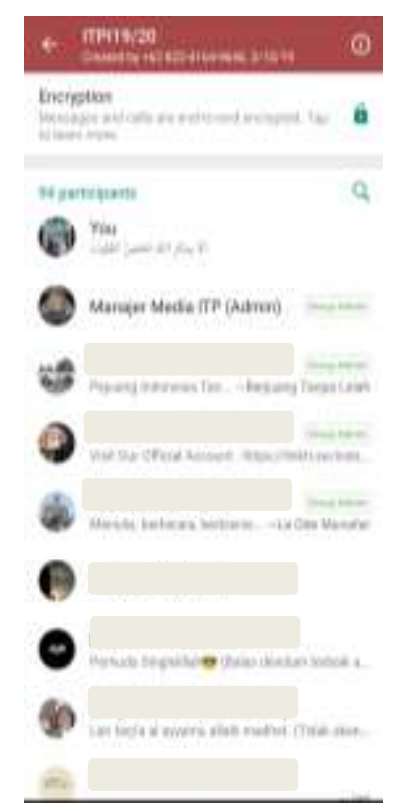

Gambar 2. Tangkapan Layar Daftar Anggota Grup Whatsapp

Berbeda dengan anggota ekskutif, member regional biasanya dijaring oleh pengurus ITP daerah/regional tanpa dibebankan biaya pendaftaran. Oleh karena itu mereka tidak mendapatkan fasilitas layaknya anggota eksekutif seperti diikutkan dalam grup Whatsapp, tidak mendapatkan aksesoris stiker, pin, serta ID Card (kecuali apabila mereka juga mendaftar sebagai anggota eksekutif). Para anggota regional ini biasanya dikordinir langsung oleh pengurus ITP daerah/regional.

Penulis mencoba bergabung menjadi anggota eksekutif ITP pada awal tahun 2020 dan kemudian dimasukkan ke dalam grup Whatsapp yang bernama "ITPI19/20". Huruf "I" di akhir nampaknya merujuk pada kata "ikhwan", kata dari bahasa Arab yang biasanya digunakan oleh mereka untuk menyebut anak/orang berjenis kelamin lakilaki, karena memang ITP memisahkan grup untuk anggotanya yang laki-laki dan perempuan. Grup "ITPI19/20" ini berisi 
anggota ITP laki-laki yang telah bergabung sejak tahun 2019 dan yang baru bergabung pada tahun 2020. Jumlah anggota di dalam grup tersebut adalah 94 orang dengan 4 diantaranya berstatus sebagai admin (lihat gambar 2).

\subsection{Pengalaman Hijrah Anggota \#IndonesiaTanpaPacaran}

Hijrah dapat didefinisikan sebagai upaya sadar dari seseorang dalam menghilangkan perilaku/kebiasaan lamanya yang dianggap buruk atau tidak sesuai dengan syariat Islam untuk berubah menjadi lebih baik dengan berusaha taat dalam menjalankan syariat Islam. Mereka yang mengidentifikasi dirinya berhijrah berarti menganggap bahwa ia mengalami perubahan perilaku. Berdasarkan penelitian yang dilakukan penulis terhadap 14 anggota ITP, perubahan perilaku dalam konteks hijrah yang mereka alami dapat mencakup berbagai aspek, diantaranya adalah:

1. Aspek penampilan, seperti perubahan dalam cara berpakaian yang menjadi lebih syar'i, dalam merias wajah (bagi perempuan) yang tidak berlebihan, menumbuhkan jenggot atau mencukur kumis, dan sebagainya.

2. Aspek keilmuan, dimana setelah berhijrah mereka memiliki kecendrungan untuk menjadi semakin haus akan wawasan keislaman, yang membuatnya memiliki kebiasaan baru untuk ikut kajian secara rutin, mengikuti akun-akun berisi wawasan keislaman di media sosial, menonton video/audio ceramah, dan membaca buku atau artikel-artikel keislaman.
3. Aspek moral, dimana setelah berhijrah mereka akan meninggalkan kebiasaankebiasaan buruknya di masa lalu, seperti pacaran, kurang berbakti kepada orang tua, sering menonton film dewasa, terlalu lama menonton drama Korea hingga menunda waktu salat, ghibah, bergaul dengan temanteman yang suka berbuat maksiat, minum-minuman keras, seks bebas, dan sebagainya.

4. Aspek spiritual, yang ditandai dengan semakin rajin untuk melaksanakan ibadah-ibadah ritual, termasuk yang hukumnya sunah seperti salat sunah, puasa sunah, mengaji, zikir, dan sebagainya. Selain itu perbaikan spiritual ini juga disebutkan oleh para informan ditandai adanya perasaan semakin dekat dengan Allah SWT.

Hijrah yang dialami oleh para responden anggota ITP dalam penelitian ini dipicu oleh berbagai macam peristiwa. Namun menariknya dari 14 responden, 5 diantaranya berhijrah karena dipicu pengalaman buruk dalam menjalani hubungan dengan lawan jenis yang mereka anggap sebagai "pacaran". Kelima informan tersebut memutuskan berhijrah setelah mereka mengalami patah hati dan kemudian menyesal telah berpacaran. Salah satunya seperti yang diutarakan oleh seorang responden $\mathrm{BI}$ dan RR berikut ini:

"Pada saat itu saya mulai merasa harus benar-benar berhijrah dan saya membulatkan tekad untuk berhijrah adalah ketika saya merasa dikecewakan oleh perempuan ... selama dua tahun di kuliah saya pacaran dengan dia .. dan saya sudah 
mau utarakan ketika saya nanti wisuda saya mau menikah dengan dia, tapi justru mungkin Allah lebih sayang kepada saya ... pada saat itu perempuan tersebut menikah dengan orang lain, meninggalkan saya ... Dan itulah yang membuat saya sangat kecewa ... disitulah kemudian saya berpikir merenungkan diri selama seminggu, saya rasa ini sudah waktunya saya meninggalkan hal-hal tersebut, hal-hal yang tidak ada manfaatnya gitu." (Responden BI)

"Saya kan sudah pacaran sejak SMA, sudah kenal keluarganya segala, nah pas sudah jalan 3 tahun 3 bulan itu saya diselingkuhin sama pacar saya mas .. dari situ akhirnya yaudahlah kita sepakat untuk nggak usah dilanjutin lagi. Setelah itu saya memikirkan ini, menyesal, kenapa saya dulu kok pacaran, kenapa kok nggak sendiri. Terus tau ITP di Instagram lihat ceramahnya kak La Ode, dari situ saya memutuskan untuk berhijrah. Ceramahnya waktu itu tentang Indonesia Darurat Pacaran." (Responden RR)

Selain dipicu oleh pengalaman buruk saat menjalani pacaran, terdapat juga responden yang berhijrah dikarenakan oleh pengalaman teman dekatnya yang meninggal di usia muda dikarenakan oleh peristiwa yang dianggapnya cukup sepele. Pengalaman ini diceritakan oleh responden $\mathrm{D}$ seperti berikut:

"Dulu itu punya temen SD yang deket banget, terus dia meninggal waktu masih kuliah di Jakarta kan. Tapi dia sakitnya itu gara-gara kebentur setirnya sepeda, itu bisa jadi sakit. Awalnya kan memang sepele, Cuma kebentur. Tapi ternyata dia didiagnosa kena kanker pankreas. Jadi dari situ kayak aku mikir ya kan umur seseorang gak bisa tau. Mau muda mau tua kalo memang waktunya udah, ya pasti udah. Jadi mikir, kan masih kayak belum punya bekal yang cukup, dari situ mikir, masih belum bisa berbakti sama orang tua." (Responden D)

Pemicu lain yang menyebabkan hijrah dari anggota ITP yang menjadi responden dalam penelitian ini cukup beragam, diantaranya adalah dikarenakan pengalaman ditinggal mati oleh orang yang disayangi, pengondisian di pesantren, tersadarkan oleh pesan dakwah yang didapatkan, merasa tidak tahu tujuan hidup di dunia dan tersadarkan setelah melihat teman sebaya yang baik agamanya. Pemicu yang disebutkan terakhir tersebut diceritakan oleh responden AR sebagai berikut:

"Jadi dulu itu sebelum hijrah saya seperti orang yang kebingungan, apa tujuan saya hidup didunia ini. Terus saya melihat teman saya, yang umurnya kurang lebih sama, tapi dia sudah bisa menjaga dirinya dari perbuatan yang buruk. Dia juga taat dalam menjalankan perintah Allah. Dari situ terus saya merenung, kok saya bisa beda jauh ya sama dia. Saya ini sudah terlalu lama menyimpang dari jalan Allah SWT. Sehingga waktu itu saya memutuskan untuk berhijrah, berusaha buat belajar Islam lebih jauh lagi biar saya bisa mengetahui apa yang sebenarnya saya cari didunia ini" (Responden AR)

Berdasarkan wawancara mendalam yang dilakukan penulis terhadap 14 responden anggota ITP tersebut hanya satu orang, yakni responden $\mathrm{RR}$, yang mengaku bahwa pengalaman hijrahnya banyak dipengaruhi oleh ITP. Pengaruh tersebut spesifiknya adalah berupa penggalan ceramah dari pendiri ITP yang diunggah pada akun Instagram resmi ITP. Sedangkan 13 responden lain 
menganggap bahwa ITP tidak berperan secara langsung terhadap keputusan hijrah mereka. Ketiga belas responden tersebut mengikuti ITP selang beberapa waktu setelah mereka memutuskan berhijrah. Keikutsertaan di ITP pun dianggap tidak begitu banyak berpengaruh terhadap hijrah mereka.

Secara alasan sendiri, kebanyakan responden (11 orang) mengaku ingin mendaftar menjadi anggota ITP setelah tertarik dengan unggahan-unggahan yang ada di media sosial ITP. Ketertarikan tersebut dikarenakan isi unggahan yang berisi kata-kata atau video pendek yang dirasa "cukup mengena" bagi mereka dan dikemas secara lucu dan "anak muda banget". Sedangkan dua orang anggota ITP yang lain, yang telah bergabung sejak tahun 2017 (D dan L) mengaku mengikuti ITP setelah tertarik dengan buku yang berjudul “\#IndonesiaTanpaPacaran", setelah melihatnya dipromosikan pada media sosial ITP. Ketika mereka membeli buku tersebut secara daring ternyata mereka secara otomatis juga dijadikan sebagai anggota gerakan ITP, dimana pada saat itu mereka diberi ID Card (bersamaan dengan buku yang dikirim) serta dimasukkan ke dalam grup Whatsapp anggota ITP. Satu orang lainnya mengaku ingin menjadi anggota ITP karena dianggapnya ITP dapat membantunya dalam proses hijrah yang sedang dijalani.

Berdasarkan analisa terhadap data-data pengalaman hijrah yang diceritakan oleh para responden dan hasil observasi yang telah dilakukan penulis, diketahui setidaknya terdapat dua faktor yang menyebabkan kenapa ITP kurang begitu banyak berpengaruh terhadap hijrah yang dialami oleh para anggotanya. Pertama adalah karena ITP kurang begitu aktif untuk memberikan pesanpesan dakwah kepada para anggotanya. Terlebih mereka cenderung hanya menjangkau para anggota melalui media sosial saja tanpa memiliki kegiatan tatap muka langsung yang rutin. Hal ini bahkan membuat para anggota eksekutif ITP cukup kecewa. Mereka menganggap bahwa ITP kurang begitu memberikan manfaat kepada mereka padahal mereka telah membayar untuk bisa menjadi anggota. Mereka menganggap ITP lebih fokus berbisnis dibandingkan berdakwah. Ini diketahui penulis berdasarkan protes yang dilayangkan oleh beberapa anggota ITP di grup Whatsapp ITPI19/20 yang juga diikuti oleh penulis seperti yang ditunjukkan dalam tangkapan layar pada gambar 3.

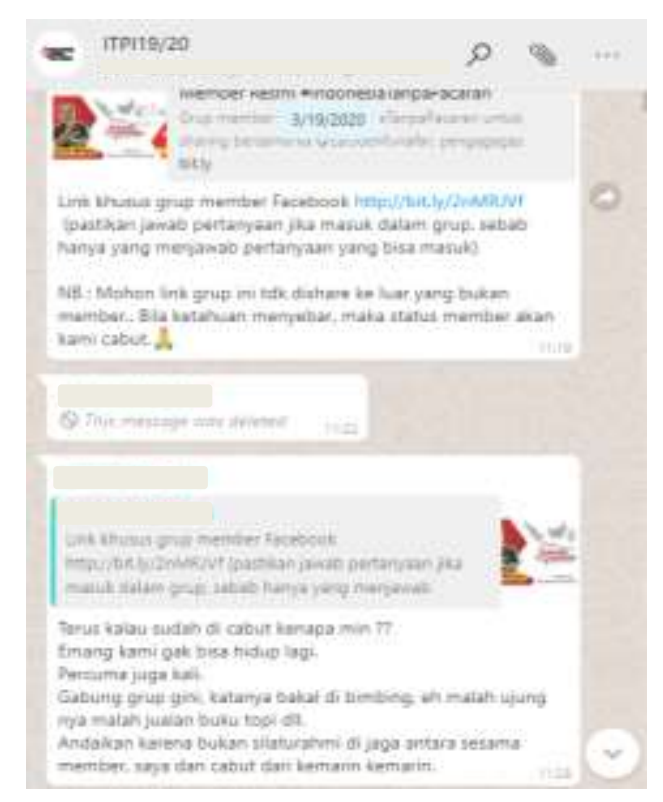

(a) 


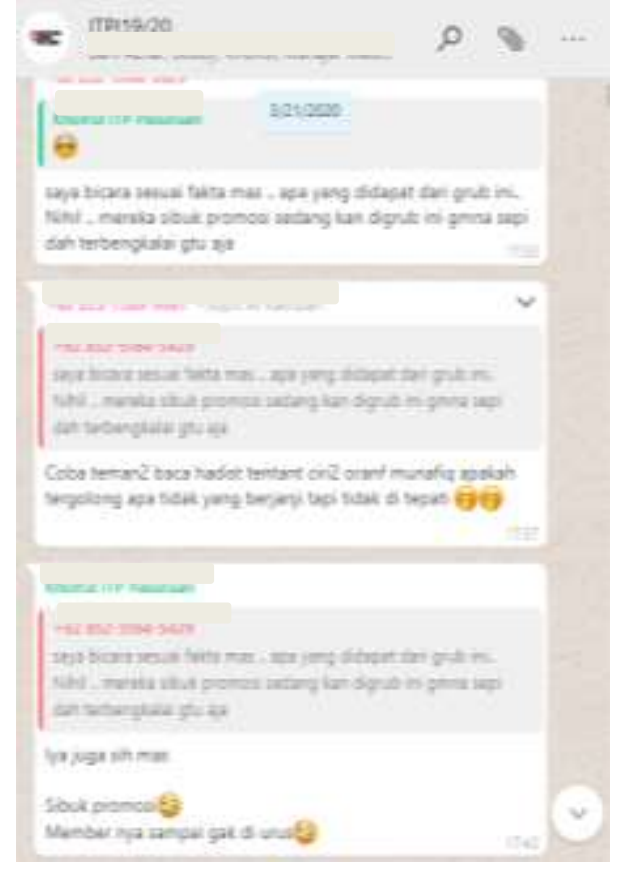

(b)

Gambar 3. (a dan b) Tangkapan Layar yang Menunjukkan Protes yang Dilayangkan Oleh Anggota ITP Di Grup Whatsapp ITPI19/20.

Kedua karena kebanyakan anggota lebih aktif berkegiatan dan berinteraksi dengan komunitas atau organisasi dakwah yang ada di sekitar mereka. Organisasi atau kelompok yang banyak membantu dalam proses hijrah para responden seringkali adalah organisasi yang melakukan dakwah secara langsung kepada mereka, bukan yang melalui media sosial atau media lain. Beberapa organisasi tersebut diantaranya adalah HMI, komunitas Pengajian Trotoar, Jamaah Tarbiyah, Wahdah Islamiyah, dan komunitas Main ke Masjid. Dengan adanya temuan ini menunjukkan bahwa stok pengetahuan yang dimiliki para responden lebih banyak dibentuk dari pengalaman mereka dengan organisasi tersebut, mengingat mereka lebih aktif mengikuti kegiatan dan berinteraksi disana dibandingkan dengan ITP. Ini dapat menjadi indikasi awal bahwa kerangka referensi para responden anggota ITP mengenai norma dan standar perilaku yang baik tidak begitu dipengaruhi oleh ITP.

\subsection{Makna Hijrah Menurut Anggota \#IndonesiaTanpaPacaran}

Para responden dalam penelitian ini memiliki pemaknaan yang seragam mengenai definisi hijrah meskipun dalam detail penjelasannya berbeda-beda. Mereka pada intinya memaknai hijrah sebagai sebuah transformasi diri yang ditandai oleh adanya perubahan perilaku dari buruk menjadi baik sesuai ajaran Islam. Contohnya adalah seperti yang diungkapkan oleh responden BS, N, dan IZR berikut ini:

"Hijrah menurut saya itu adalah perubahan diri menjadi lebih baik, khususnya dalam beragama dengan bersikap sesuai yang diajarkan oleh Al-Qur'an dan Sunah" (Responden $\mathrm{BS})$

"Hijrah bagi saya adalah metamorfosis dan evolusi akhlak dari yang dulunya masih masa jahiliyah menuju masa syariah" (Responden N)

"Bagi saya hijrah itu perpindahan atau bisa dibilang berubahnya seseorang dari yang belum taat menjadi lebih taat lagi, sehingga perilakunya menjadi lebih baik, karena dia tahu mana yang salah dan benar, mana yang diperbolehkan dan yang diharamkan, dan orang itu akan mengontrol jika ada perilakunya tidak baik" (Responden IZR)

Pemaknaan yang hampir seragam mengenai pengertian hijrah ini memiliki kemiripan dengan makna hijrah yang memang sedang populer di kalangan anak muda saat ini, yang menganggap hijrah sebagai suatu 
perubahan perilaku dari buruk menjadi baik, atau dari yang belum taat menjalankan ajaran Islam menjadi lebih taat (Nuriz 2019).

Pemaknaan yang cenderung berbeda muncul ketika mereka menginterpretasikan "perilaku baik yang sesuai ajaran Islam". Ini terjadi lantaran ajaran Islam memang sangat dimungkinkan untuk diinterpretasikan secara berbeda oleh umatnya. Buktinya dapat dilihat dari banyaknya perbedaan pendapat mengenai berbagai penerapan ajaran Islam dalam kehidupan sehari-hari, seperti dalam menentukan wajib tidaknya berjilbab, haram tidaknya musik, bunga bank, foto, dan sebagainya. Kondisi ini juga terjadi pada para responden anggota ITP. Salah satunya yang menjadi fokus dalam penelitian ini adalah mengenai pandangan mereka terhadap perlunya penerapan syariat Islam di masyarakat, mengingat isu tersebut merupakan agenda utama dari gerakan ITP yang berpotensi menimbulkan permasalahan.

Penulis menemukan bahwa dari 14 anggota ITP yang menjadi responden, hanya tiga yang memiliki perhatian khusus pada isu penegakkan syariat Islam sebagai bagian dari implementasi hijrah mereka. Ketiga responden tersebut adalah responden Y, BA, dan BS:

"Menurut saya saat ini pembentukan karakter islami pada generasi kita sangat minim, perlu adanya peran lingkungan yang mendukung pembentukan karakter islami dan bahayanya pergaulan bebas untuk anak-anak muda kita, oleh karena itu kita sebagai seorang muslim yang paham, terlebih yang menganggap dirinya telah berhijrah harus berusaha untuk berdakwah, memperjuangkan agar syariat Islam itu bisa dijalankan di masyarakat." (Responden Y)
"Di negara kita saat ini masyarakatnya masih setengahsetengah dan terkesan ragu-ragu dalam menjalankan syariah. Bunga bank yang haram masih dijalankan, pemimpin non muslim juga masih didukung. Oleh karena itu menurut saya sebagai orang yang berhijrah kita harusnya perlu berdakwah agar syariah ini bisa ditegakkan" (Responden BS)

"Setau saya itu Islam luas, tidak terbatas cuma salat, puasa, ngaji saja. Islam juga ngatur ekonomi, pergaulan, dan lainnya. Hanya saja sekarang tidak semuanya diterapkan sehingga muncul masalah-masalah. Makanya kita harus berdakwah agar syariat Islam itu diterapkan di semua lini di masyarakat." (Responden BA)

Sebelas responden yang lain tidak menjadikan isu penegakkan syariat Islam sebagai hal yang utama dalam hijrah mereka. Mereka lebih fokus pada usaha untuk memperbaiki diri mereka sendiri dibandingkan memikirkan penerapan syariat Islam untuk menyelesaikan persoalan masyarakat. Salah satu contohnya seperti yang diungkapkan oleh responden $\mathrm{L}$ yang menganggap bahwa perbaikan atau dakwah di masyarkat bukan merupakan tanggung jawabnya:

"Katanya sih ya kita gak bisa merubah seseorang kalau kita gak merubah diri sendiri. Makanya kadang itu saya kalau misalnya bilangin temen yaudah gini aja, tapi ya di sisi lain mereka juga akan membandingkan dengan perilaku saya. Maka dari itu dakwah ya harus dari diri sendiri, terus kedua, dakwahnya ke orang-orang terdekat dulu sih ... Jadi dimulai dari keluarga terdekat dulu. InsyaAllah baru ke temen-temen. Kalau ke masyarakat luas sih, bukan ke ranahku." (Responden L) 
Tidak adanya perhatian pada isu syariat Islam oleh sebelas responden tersebut juga terkonfirmasi dari observasi yang dilakukan oleh peneliti terhadap unggahanunggahan media sosial mereka yang sama sekali tidak menyinggung isu-isu penerapan syariat Islam, termasuk mengenai khilafah Islamiyah.

Selain perbedaan dalam memandang isu mengenai penegakkan syariat Islam di masyarakat, para responden juga memiliki perbedaan dalam memahami tentang beberapa penerapan ajaran Islam lainnya. Salah satunya mengenai penampilan. Salah satu responden laki-laki (responden A) memandang bahwa hijrah tidak melulu soal penampilan seperti yang diungkapkannya berikut ini:

"Hijrah itu kan sebenarnya tidak
dinilai dari penampilan ya.
Sebenarnya hijrah itu kan sama saja
kayak proses perbaikan diri, dari yang
ini jadi ini. Cuma yang saya bingung
itu ya apa harus ya hijrah itu
penampilannya berubah gitu, kayak
berjenggot, celana cingkrang, pakai
gamis malahan. Apakah orang biasa
kayak saya, pakai celana jeans, pakai
kaos, itu apakah nggak bisa dinilai
hijrah gitu. Jadi menurut saya hijrah
itu kalau dari arti kan berpindah,
hijrah itu kan harus lebih baik dari
kemarin. Dalam ibadahnya jadi lebih
baik, akhlaknya juga harus terus
berusaha diperbaiki." (Responden A)

Pemahaman mengenai penampilan ini berbeda dengan seluruh responden perempuan yang menganggap bahwa sebagai perempuan harus berpenampilan syar'i dengan mengenakan jilbab lebar, tidak berpakaian ketat, serta menggunakan kaos kaki (karena menganggap telapak kaki sebagai aurat). Yang menarik, terdapat salah satu responden, yakni responden SKA, yang meyakini keharusan berpenampilan syar' $i$ tersebut namun ia tidak menerapkannya meski mengaku telah berhijrah:

"Mereka yang sedari awal ikut ITP itu hijrahnya sudah yang subhanallah, dari pakaiannya, penampilannya, semua sudah bener-bener syar'i. Tapi saya bilang, saya pingin menikmati proses hijrah ini. Saya gak mau kalau hijrah itu hanya sekedar fenomena, istilahnya hanya mengikuti tren. Saya gak mau seperti itu. Saya ingin menikmati ya sesuai proses saya. Yang pasti ke depan aku mencoba lebih baik lagi dalam segi pakaian. Saat ini saya memang belum bisa, belum mampu untuk melakukan itu, tapi suatu saat saya pasti punya keinginan untuk kesitu." (Responden SKA)

ITP sebagai gerakan yang cenderung berpemahaman konservatif, memiliki beberapa pandangan yang cenderung kaku dalam menerapkan ajaran Islam. Salah satunya adalah mengenai larangan ikhtilat, yakni larangan untuk bercampur baur antara laki-laki dan perempuan dalam satu ruangan. Konsep ini memang tidak begitu populer di masyarakat Indonesia mengingat berbagai kegiatan di masyarakat kita hampir semuanya dilakukan tanpa memisahkan antara laki-laki dan perempuan, seperti dalam kegiatan belajar mengajar di sekolah ataupun kampus, resepsi pernikahan, kampanye, pertandingan sepak bola, dan sebagainya. Namun larangan ini beberapa kali justru diwacanakan oleh ITP pada unggahan-unggahan media sosial mereka, salah satunya seperti yang ditampilkan pada gambar 4 di bawah ini: 


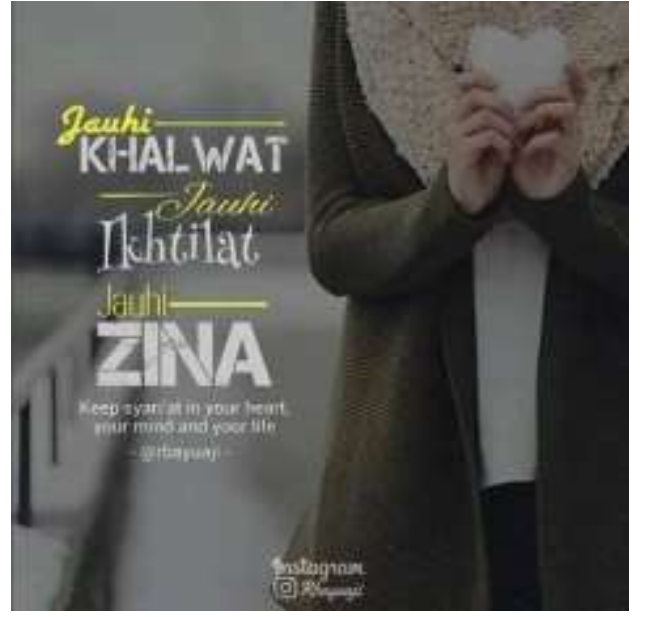

Gambar 4. Unggahan Pada Akun Facebook ITP yang Berisi Pesan untuk Menjauhi Ikhtilat

(Sumber: Facebook.com)

Selain itu, La Ode Munafar juga memberi perhatian khusus pada isu ikhtilat ini seperti yang ia tunjukkan ketika menjelaskan alasan ia menyebut Indonesia sebagai negara sekuler. Meski demikian, para responden dalam penelitian nampak tidak mengetahui definisi dari ikhtilat. Mereka juga nampak tidak mempermasalahkan adanya interaksi antara laki-laki dan perempuan dalam satu ruangan. Para responden perempuan bahkan melakukan wawancara dengan penulis secara langsung tanpa memberi batasan apapun. Ini menunjukkan bahwa salah satu ajaran Islam yang dipahami oleh ITP dan cukup ditekankan oleh mereka dalam pesan-pesan dakwahnya, ternyata tidak begitu dipahami oleh para anggotanya.

Berdasarkan temuan-temuan yang didapatkan, penulis melihat bahwa pemikiran ITP tidak banyak diadopsi oleh para anggotanya, yang terlihat dari penjelasan para responden ketika mengungkapkan tentang makna hijrah dan implementasinya. Hal ini wajar karena ternyata hampir semua responden hanya mengakses pesan-pesan dakwah ITP melalui media sosial, itupun mereka sebenarnya tidak mengehendaki atau meniatkan untuk membuka akun ITP. Mereka hanya men-scroll beranda pada akun Instagram atau Facebook-nya, dan akan membaca unggahan dari ITP apabila unggahan tersebut muncul. Hanya ada satu responden, dari 14 orang, yang membaca buku-buku ITP, termasuk buku berjudul “\#IndonesiaTanpaPacaran". Padahal buku tersebut berisi konsep-konsep yang melandasi ITP dan menjelaskan arah pergerakan mereka.

\section{Simpulan dan Saran}

Berdasarkan analisa yang telah dilakukan terhadap data-data yang berhasil dikumpulkan dalam penelitian ini, penulis menemukan bahwa hampir seluruh responden anggota ITP memiliki pengalaman hijrah yang tidak banyak dipengaruhi oleh ITP. Hijrah mereka justru lebih banyak dipengaruhi oleh organisasi atau kelompok dakwah yang berada di sekitar mereka. Ini disebabkan dua faktor, yang pertama karena ITP kurang aktif melakukan dakwah terhadap para anggotanya dan yang kedua karena para anggota ITP lebih aktif berkegiatan dan mendapatkan paparan dakwah dari organisasi atau kelompok dakwah yang ada di sekitar mereka.

Temuan lain dalam penelitian ini menunjukkan bahwa para anggota ITP memaknai hijrah sebagai proses perubahan diri untuk menjadi lebih baik sesuai ajaran Islam. Para responden anggota ITP mayoritas (11 orang) tidak memiliki keinginan atau perhatian 
khusus terhadap upaya penerapan syariat Islam di masyarakat. Mereka nampak lebih memfokuskan hijrahnya pada perbaikan diri sendiri dibandingkan memikirkan solusi untuk permasalahan sosial melalui penerapan syariat Islam. Hanya ada 3 responden yang menaruh perhatian lebih terhadap isu penerapan syariat Islam. Penulis juga mendapati temuan bahwa para responden tidak begitu memahami beberapa konsep penting yang diwacanakan oleh ITP. Salah satunya seperti konsep larangan ikhtilat. Padahal konsep ini merupakan salah satu yang cukup konsisten mereka dakwahkan dalam berbagai kanal dakwah yang mereka miliki.

Berdasarkan beberapa temuan tersebut penulis dapat menyimpulkan bahwa para responden anggota ITP tidak memiliki konsep hijrah yang sama dengan ITP. Mereka juga tidak memiliki ikatan yang cukup kuat terhadap ITP meskipun berstatus sebagai anggota dan justru lebih dekat dengan organisasi atau kelompok lain yang ada di sekitar mereka. Maka dari itu dapat dikatakan bahwa propaganda hijrah ITP nampak kurang berhasil, bahkan kepada para anggotanya sendiri yang telah bergabung minimal selama 6 bulan.

\section{Daftar Pustaka}

Ahnaf, Mohammad Iqbal. 2018. "Hizb AlTahrir: Its Ideology and Theory for Collective Radicalization." In Expressions of Radicalization: Global Politics, Processes and Practices, edited by Kristian Steiner and Andreas Önnerfors, 295-320. Cham: Springer International Publishing. https://doi.org/10.1007/978-3-31965566-6_11.
Al-Jauziyah, Ibnul Qayyim. 2002. Bekal Hijrah Menuju Allah. Depok: Gema Insani.

Ardian, Donny Gahral. 2016. Pengantar Fenomenologi. Depok: Koekoesan.

Aswadi. 2011. "Reformulasi Epistemologi Hijrah Dalam Dakwah." Jurnal Islamica 5 (2): 339-52.

Bruinessen, Martin van. 2013. Contemporary Developments in Indonesian Islam: Explaining the "Conservative Turn." Pasir Panjang: ISEAS Publishing.

CNN Indonesia. 2019. "Curhat Hijrah Para Ukhti Di Indonesia Tanpa Pacaran." 2019.

https://www.cnnindonesia.com/nasional/ 20190517194056-20-395913/curhathijrah-para-ukhti-di-indonesia-tanpapacaran/2.

Creswell, John W. 2015. Penelitian Kualitatif Dan Desain Riset: Memilih Di Antara Lima Pendekatan. 3rd ed. Yogyakarta: Pustaka Pelajar.

Geotimes. 2018. "Indonesia Tanpa Pacaran Bergaun Kapital." 2018. https://geotimes.co.id/opini/indonesiatanpa-pacaran-bergaun-kapital/.

Haryanto, Sindung. 2012. Spektrum Teori Sosial: Dari Klasik Hingga Postmodern. Sleman: Ar-Ruzz Media.

IDN Times. 2018. "Eksklusif: Mengenal Gagasan Gerakan Indonesia Tanpa Pacaran." 2018. https://www.idntimes.com/news/indonesi a/indianamalia/eksklusif-mengenalgagasan-gerakan-indonesia-tanpapacaran-1/3.

Indonesiatanpapacaran. 2017. "Profil Gerakan \#IndonesiaTanpaPacaran." 2017. http://indonesiatanpapacaran.com/2017/0 1/21/profil-gerakanindonesiatanpapacaran/.

Kompas.com. 2017. "HTI Resmi Dibubarkan Pemerintah." 2017. https://nasional.kompas.com/read/2017/0 7/19/10180761/hti-resmi-dibubarkanpemerintah?page=all. 
Morissan. 2015. Teori Komunikasi Individu Hingga Massa. Jakarta: Kencana.

Munafar, La 2018. \#IndonesiaTanpaPacaran. Bantul: Gaul Fresh.

Nuriz, M. Afthon Lubbi. 2019. "Generasi Muda Milenial Dan Masjid Di Era Digital." In Masjid Di Era Milenial: Arah Baru Literasi Keagamaan, edited by Jajang Jahroni and Irfan Abubakar, 157-82. Jakarta: Center for the Study of Religion and Culture.

Sari, Trie Yunita. 2019. "Hijrah and Islamic Movement in Cyberspace A Social Movement Study of Anti- Dating Movement \#IndonesiaTanpaPacaran." Universitas Gajah Mada.

Syam, Nina Winangsih. 2015. Komunikasi Transendental: Perspektif Sains Terpadu. Bandung: Remaja Rosdakarya.

Taylor, Steven J., Robert Bogdan, and Marjorie L. DeVault. 2016. Introduction to Qualitative Research. 4th ed. Hoboken: Wiley.

Tirto.id. 2018. "Bisnis Dan Kontroversi Gerakan Indonesia Tanpa Pacaran." 2018. https://tirto.id/cK25.

Zahavi, Dan. 2019. Phenomenology The Basics. New York: Routledge.

Internet:

CNN Indonesia. 2019. "Curhat Hijrah Para Ukhti di Indonesia Tanpa Pacaran." 2019.

https://www.cnnindonesia.com/nasional/ 20190517194056-20-395913/curhathijrah-para-ukhti-di-indonesia-tanpapacaran/2.

Geotimes. 2018. "Indonesia Tanpa Pacaran Bergaun Kapital." 2018. https://geotimes.co.id/opini/indonesiatanpa-pacaran-bergaun-kapital/.

IDN Times. 2018. "Eksklusif: Mengenal Gagasan Gerakan Indonesia Tanpa Pacaran." 2018. https://www.idntimes.com/news/indonesi a/indianamalia/eksklusif-mengenal- gagasan-gerakan-indonesia-tanpapacaran-1/3.

Indonesiatanpapacaran. 2017. "Profil Gerakan \#IndonesiaTanpaPacaran." 2017. http://indonesiatanpapacaran.com/2017/0 1/21/profil-gerakanindonesiatanpapacaran/.

Kompas.com. 2017. "HTI Resmi Dibubarkan Pemerintah." 2017. https://nasional.kompas.com/read/2017/0 7/19/10180761/hti-resmi-dibubarkanpemerintah?page $=$ all.

Tirto.id. 2018. "Bisnis dan Kontroversi Gerakan Indonesia Tanpa Pacaran." 2018. https://tirto.id/cK25. 